\title{
PERANCANGAN APLIKASI ANDROID SISTEM INFORMASI AKADEMIK UNIVERSITAS KHAIRUN TERNATE
}

\author{
Muhammad Randy Gelby Hattari ${ }^{1}$, Salkin Lutfi $i^{2}$, Amal Khairan ${ }^{3}$ \\ Program Studi Teknik Informatika, Fakultas Teknik, Universitas Khairun \\ E-mail : hattari.mrandygelby@gmail.com ${ }^{1}$, salkin.lutfi@gmail.com² \\ ibntawakkal@gmail.com ${ }^{3}$
}

\begin{abstract}
Abstact -- Khairun University (Unkhair) has an academic information system in the form of web applications. Academic information system academic web applications can be accessed through a variety of devices one of them with mobile devices, but when opened via mobile devices its size remains the same size on the web and open intact so it looks quite small appearance and need to zoom repeatedly to read and there is a sensitive menu. Development of this application based on android so it can run on smartphone device, and Android is operating system on mobile which is open and based on Linux operating system. Development of this research using prototype method, where there are 3 process in design that is listening customer, build and design system, and testing customer. The application of this mobile academic information system application includes two important users in the academic process are students and lecturers. The results of testing the application of each user result that the user can access the system of academic mobile information has been according to the needs of each user, so this application is said successful and ready to use.
\end{abstract}

\section{Keyword : Academic Information System, Android, Prototype}

Abstrak -- Universitas Khairun (Unkhair) telah memiliki sistem informasi akademik dalam bentuk aplikasi web. Aplikasi web sistem informasi akademik dapat diakses melalui berbagai perangkat salah satunya dengan perangkat mobile, namun ketika dibuka melalui perangkat mobile ukuran nya tetap sama dengan ukuran pada web dan terbuka utuh sehingga terlihat cukup kecil tampilannya dan butuh zoom berulang kali untuk terbaca dan terdapat menu yang sensitif. Pembangunan aplikasi ini berbasis android sehingga dapat berjalan pada perangkat smarthphone, dan Android merupakan sistem operasi pada handphone yang bersifat terbuka dan berbasis pada sistem operasi Linux. Pengembangan penelitian ini mmenggunakan metode prototype, dimana terdapat 3 proses dalam perancangan yaitu mendengarkan pelanggan, membangun dan merancang sistem, serta pengujian pelanggan. Penerapan aplikasi mobile sistem informasi akademik ini mencakup dua user penting dalam proses akademik yaitu mahasiswa dan dosen. Hasil pengujian aplikasi dari masing-masing user menghasailkan bahwa user dapat mengakses sistem informasi akademik mobile telah sesuai kebutuhan masing - masing user, sehingga aplikasi ini dikatakan berhasil dan siap digunakan.

Kata Kunci : Sistem Informasi Akademik, Android, Prototype

\section{PENDAHULUAN}

1.1 Latar Belakang

Univeritas Khairun merupakan salah satu perguruan tinggi negeri di Maluku Utara yang berdiri sejak tahun 1964. Universitas Khairun sampai saat ini telah memiliki 8 fakultas yang terdapat di 3 letak kampus, yaitu kampus 1 Akehuda, kampus 2 Gambesi, dan kampus 3 Jati.

Mahasiswa yang berminat melanjutkan pendidikan bangku kuliahnya di Universitas Khairun semakin besar dari tahun ke tahun. Untuk mengelola administrasi akademik dengan jumlah mahasiswa yang banyak maka pada tahun 2016 telah diluncurkan sebuah aplikasi web Sistem Inforamasi Akademik. Aplikasi ini dapat membantu efektifitas dan efesiensi pengolahan data di Universitas Khairun. Mulai dari proses registrasi hingga perbelanjaan mata kuliah. Pekerjaan tata usaha, dosen, dan mahasiswa terasa lebih mudah dan nyaman. Yang dulunya perlu menunggu lama hasil cetakan kartu hasil studi (KHS), menunggu kartu rencana studi (KRS), perlu ke ruangan tata usaha untuk meminta transkip nilai, dan mencari jadwal di mading-mading kini hal tersebut dapat dilalukan hanya lewat browser PC, laptop, maupun perangkat mobile kita.

Adanya aplikasi web Sistem Informasi Akademik di Universitas Khairun memungkin segala hal administrasi kampus dapat dilakukan dimana saja dan kapan saja. Namun kendala aplikasi web Sistem Informasi Akademik yaitu ketika dibuka melalui perangkat mobile ukuran nya tetap sama dengan ukuran pada web dan terbuka utuh sehingga terlihat cukup kecil tampilannya dan butuh zoom berulang kali untuk terbaca. Begitu juga beberapa menu yang cukup sensitif yang ketika dibuka lewat perangkat mobile perlu kesabaran dan kecepatan karena jika terlambat maka halamannya muncul kembali.

Berdasarkan fenomena tersebut diatas maka dipandang perlu melakukan pengembangan dari aplikasi web Sistem Informasi Universitas Khairun Ternate menjadi aplikasi mobile. Maka penulis 
mengambil judul tentang "Perancangan Aplikasi Android Sistem Informasi Akademik Universitas Khairun Ternate".

1.2 Tujuan Penelitian

Tujuan penilitian ini yaitu merancang aplikasi android sistem informasi akademik Universitas Khairun Ternate.

1.3 Manfaat Penelitian

Manfaat yang diharapkan dari penelitian ini adalah:

1. Memudahkan aplikasi sistem informasi akademik Universitas Khairun ketika dibuka lewat perangkat seluler.

2. Efisiensi waktu dalam proses administrasi yang berlangsung.

3. Sebagai tolak ukur implementasi ilmu penulis pada bangku kuliah.

4. Menambah wawasan dalam bidang ilmu terkait dengan judul yang diangkat.

\section{TINJAUAN PUSTAKA}

A. Sistem Informasi Akademik Universitas Khairun Sistem Informasi Akademik Universitas Khairun merupakan sebuah aplikasi yang dibangun untuk keperluan administrasi pada Universitas Khairun. Pada aplikasi ini memungkin segala hal administrasi kampus dapat dilakukan dimana saja dan kapan saja.

Baik dalam hal perencanaan kartu rencana studi hingga pengurusan nilai mahasiswa dan jadwal perkuliahan.

Sistem Informasi Akademik Universitas Khairun pertama kali di kembangkan oleh program studi Teknik Informatika, yang kemudian dipakai untuk keseluruhan universitas pada tahun 2015. Sehingga segala hal yang berkaitan dengan administrasi sudah dapat dilakukan dengan mudah dan efektif.

B. Android $O S$

Menurut Nasruddin Safaat (2012) android adalah sebuah sistem operasi pada handphone yang bersifat terbuka dan berbasis pada sistem operasi Linux. Android bisa digunakan oleh setiap orang yang ingin menggunakannya pada perangkat mereka. Android menyediakan platform terbuka bagi para pengembang untuk menciptakan aplikasi mereka sendiri yang akan digunakan untuk bermacam peranti bergerak [3].

C. Android Studio

Android Studio adalah sebuah IDE yang bisa digunakan untuk pengembangan aplikasi Android, dan dikembangkan oleh Google. Android Studio merupakan pengembangan dari Eclipse IDE, dan dibuat berdasarkan IDE Java populer, yaitu IntelliJ IDEA. Android Studio direncanakan untuk menggantikan Eclipse ke depannya sebagai IDE resmi untuk pengembangan aplikasi Android. Sebagai pengembangan dari Eclipse, Android Studio mempunyai banyak fitur-fitur baru dibandingkan dengan Eclipse IDE. Berbeda dengan Eclipse yang menggunakan ADT, Android Studio menggunakan Gradle sebagai build environment [1].

\section{Java}

Java menurut definisi dari Sun adalah nama untuk sekumpulan teknologi untuk membuat dan menjalankan perangkat lunak pada komputer standalone ataupun pada lingkungan jaringan. Java 2 adalah generasi kedua dari java platform. Kata berdiri di atas sebuah mesin interpreter yang diberi nama Java Virtual Machine (JVM). JVM inilah yang akan membaca bytecode dalam file, class dari suatu program sebagai representasi langsung dari program yang berisi bahasa mesin. Oleh karena itu, bahasa java disebut sebagai bahasa pemrograman yang portable karena dapat dijalankan pada berbagai sistem operasi, asalkan pada sistem operasi tersebut terdapat JVM [5].

\section{E. $P H P$}

PHP (Hypertext Preprocessor) adalah sebuah bahasa pemrograman yang berbentuk scripting, sistem kerja program ini adalah sebagai Interpreter bukan sebagai Compiler. PHP menurut Syafii didalam Moh. Ihsan Alhudri (2004) merupakan bahasa pemrograman berbasis web yang terbukti sangat reliable penggunaannya dan mempunyai dukungan yang kuat [2].

F. $M y S Q L$

MySQL adalah sebuah perangkat lunak sistem manajemen basis data $S Q L$ atau $D B M S$ yang multithread, multi-user, dengan sekitar 6 juta instalasi di seluruh dunia [4].

\section{METODE PENELITIAN}

\section{A. Pengembangan Perangkat Lunak}

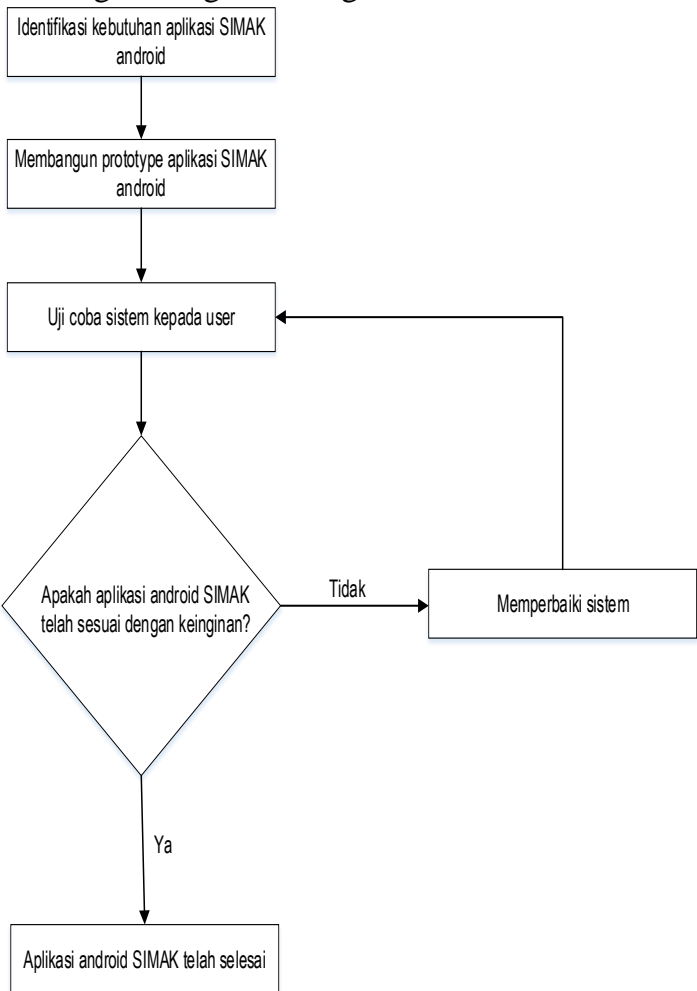

Gambar 1 Pengembangan Perangkat Lunak Menggunakan Prototipe 
Deskripsi Pengembangan Sistem:

1. Mengidentifikasi kebutuhan-kebutuhan dalam hal ini kebutuhan dalam data Aplikasi Android SIMAK UNKHAIR.

2. Membangun Prototype Aplikasi Android SIMAK UNKHAIR berdasarkan kebutuhan.

3. Setelah membuat prototype dari sistem kemudian membangun dan menggunakan Aplikasi Android SIMAK UNKHAIR menggunakan Bahasa Pemograman JAVA dan PHP.

4. Setelah itu, lanjut ke tahap pengujian dengan melibatkan user.

5. Jika dalam tahapan pengujian ditemukan Aplikasi Android SIMAK UNKHAIR belum lengkap maka dilakukan perbaikan dengan meningkatkan sistem berdasarkan kebutuhan yang baru.

6. Apabila Aplikasi Android SIMAK UNKHAIR telah lengkap maka selesai. Apabila tidak lengkap maka kembali memperbaiki sistem tersebut.

\section{B. Use Case Diagram}

Use Case adalah deskripsi dari urutan aksi-aksi yang ditampilkan sistem yang menghasilkan suatu hasil yang terukur bagi suatu actor. Use Case disini terdiri dari tiga yaitu Use Case User Dosen dan Use Case User Mahasiswa.

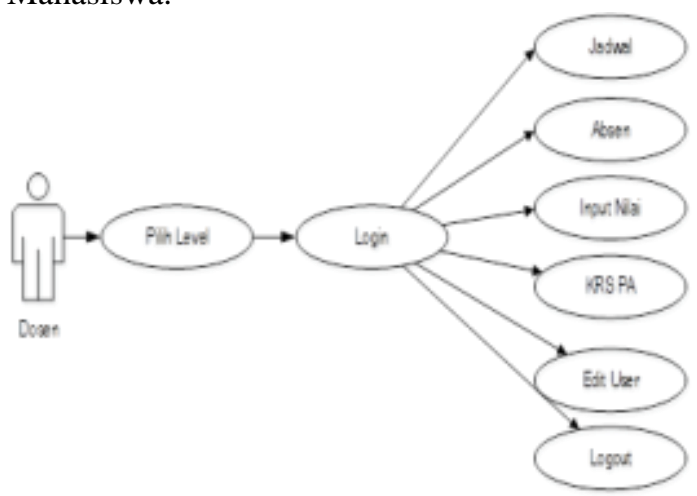

Gambar 2 Use Case Diagram Dosen

Deskripsi Use Case Dosen:

Pada bagian use case diagram ini, ketika dosen membuka aplikasi akan tertampil halaman pilih level kemudian saat level dosen dipilih muncul halaman form login yang akan mengantarkan dosen kedalam halaman utama aplikasi lengkap dengan keseluruhan menunya. Terdapat beberapa menu yaitu menu KRS Mahasiswa PA yang memungkinkan dosen untuk memantau KRS mahasiswa PA-nya, kemudian menu melihat jadwal dimana dosen dapat melihat keseluruhan jadwal perkuliahan yang di ajarkannya, menu Input Nilai disini dosen dapat melihat dan mengisi nilai pada matakuliah yang diajarkan dan pada menu absen dosen dapat mencetak absen berdasarkan matakuliah yang diajarkan. Dan pada menu logout akan mengantarkan mahasiswa kembali ke halaman login dari aplikasi,

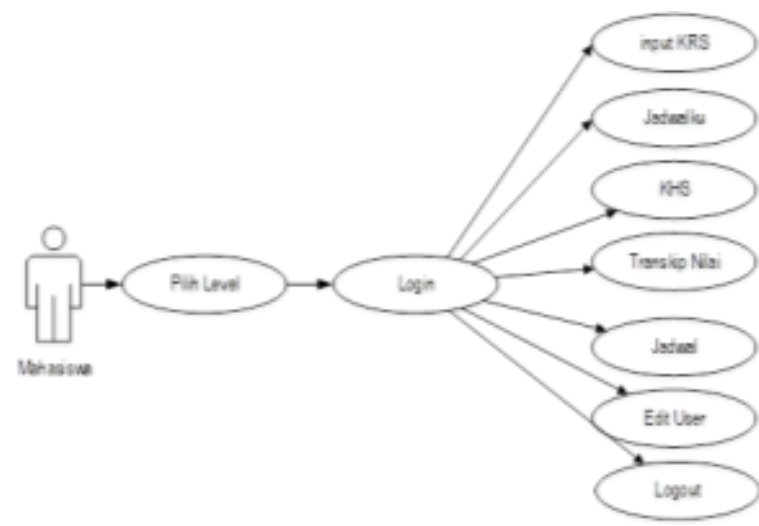

Gambar 3 Use Case Diagram Mahasiswa

Deskripsi Use Case Mahasiswa:

Pada bagian use case diagram ini, ketika mahasiswa membuka aplikasi akan tertampil halaman pilih level kemudian saat level mahasiswa dipilih muncul halaman form login yang akan mengantarkan mahasiswa kedalam tampilan halaman utama aplikasi lengkap dengan keseluruhan menunya. Terdapat beberapa menu yaitu menu input dan jadwalku yang memungkinkan mahasiswa untuk melihat KRS semester berjalan atau menginput KRS-nya, kemudian menu melihat jadwal dimana mahsiswa dapat melihat keseluruhan jadwal perkuliahan, menu KHS disini mahasiswa dapat melihat KHS-nya baik pada semester ganjil maupun semester genap pada tahun ajaran yang sedang berjalan maupun yang sudah lewat, dan pada menu transkip nilai mahasiswa dapat melihat hasil studinya selama perkuliahan. Dan pada menu logout akan mengantarkan mahasiswa kembali ke halaman login dari aplikasi,

C. Kamus Data

Kamus data merupakan bagian dari perancangan sistem yang berisi field-field yang diperlukan oleh suatu database untuk menjalankan sistem yang telah dibuat. Kamus data dapat dikatakan sebagai penjelasan dari field-field dalam table database.

Tabel 1. Tabel msmhs

\begin{tabular}{|c|l|c|c|l|}
\hline No & \multicolumn{1}{|c|}{ Nama Field } & $\begin{array}{c}\text { Tipe } \\
\text { Data }\end{array}$ & $\begin{array}{c}\text { Lebar } \\
\text { Data }\end{array}$ & \multicolumn{1}{|c|}{ Ket. } \\
\hline 1 & Idmsmh* & Bigint & 20 & id mahasiswa \\
\hline 2 & NIMMSMHS & Varchar & 15 & nim mahasiswa \\
\hline 3 & KDPSTMSMHS & Varchar & 5 & Kode prodi \\
\hline 4 & NMMHSMSMHS & Varchar & 30 & $\begin{array}{l}\text { nama } \\
\text { mahasiswa }\end{array}$ \\
\hline 5 & TPLHRMSMHS & Varchar & 20 & $\begin{array}{l}\text { tempat lahir } \\
\text { mahasiswa }\end{array}$ \\
\hline 6 & TGLHRMSMHS & Date & - & $\begin{array}{l}\text { tanggal lahir } \\
\text { mahasiswa }\end{array}$ \\
\hline 7 & Dosenpa & Varchar & 10 & $\begin{array}{l}\text { dosen PA } \\
\text { mahasiswa }\end{array}$ \\
\hline 8 & Email & Varchar & 60 & $\begin{array}{l}\text { email } \\
\text { mahasiswa }\end{array}$ \\
\hline 9 & Alamat & Text & - & $\begin{array}{l}\text { alamat } \\
\text { mahasiswa }\end{array}$ \\
\hline 10 & Password & Varchar & 100 & $\begin{array}{l}\text { password } \\
\text { mahasiswa }\end{array}$ \\
\hline
\end{tabular}


Perancangan Aplikasi Android Sistem Informasi Akademik Universitas Khairun Ternate

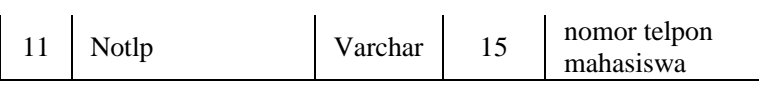

Tabel 2. Tabel msdos

\begin{tabular}{|c|l|c|c|l|}
\hline No & \multicolumn{1}{|c|}{ Nama Field } & $\begin{array}{c}\text { Tipe } \\
\text { Data }\end{array}$ & $\begin{array}{c}\text { Lebar } \\
\text { Data }\end{array}$ & \multicolumn{1}{|c|}{ Ket. } \\
\hline 1 & Idmsdos* & Bigint & 20 & id dosen \\
\hline 2 & NODOSMSDOS & Varchar & 10 & nomor dosen \\
\hline 3 & KDPTIMSDOS & Varchar & 6 & $\begin{array}{l}\text { kode perguruan } \\
\text { tinggi }\end{array}$ \\
\hline 4 & KDPSTMSDOS & Varchar & 5 & Kode prodi \\
\hline 5 & NMDOSMSDOS & Varchar & 30 & nama dosen \\
\hline 6 & NIDNNMSDOS & Varchar & 10 & $\begin{array}{l}\text { nomor NIDN } \\
\text { dosen }\end{array}$ \\
\hline 7 & GELARMSDOS & Varchar & 10 & gelar dosen \\
\hline 8 & TPLHRMSDOS & Varchar & 20 & $\begin{array}{l}\text { tempat lahir } \\
\text { dosen }\end{array}$ \\
\hline 9 & TGLHRMSDOS & Date & - & $\begin{array}{l}\text { tanggal lahir } \\
\text { dosen }\end{array}$ \\
\hline 10 & Password & Varchar & 100 & password dosen \\
\hline 11 & Alamat & Varchar & 50 & alamat dosen \\
\hline 12 & Email & Varchar & 60 & email dosen \\
\hline
\end{tabular}

Tabel 3. Tabel mspst

\begin{tabular}{|c|l|c|c|l|}
\hline No & \multicolumn{1}{|c|}{ Nama Field } & $\begin{array}{c}\text { Tipe } \\
\text { Data }\end{array}$ & $\begin{array}{c}\text { Lebar } \\
\text { Data }\end{array}$ & \multicolumn{1}{|c|}{ Ket. } \\
\hline 1 & Idpst* & Bigint & 20 & id prodi \\
\hline 2 & KDPSTMSPST & Varchar & 5 & kode prodi \\
\hline 3 & NMPSTMSPST & Varchar & 40 & nama prodi \\
\hline 4 & TGAWLMSPST & Date & - & $\begin{array}{l}\text { tanggal berdiri } \\
\text { prodi }\end{array}$ \\
\hline 5 & SKSTTMSPST & Decimal & 3,0 & $\begin{array}{l}\text { sks tertinggi } \\
\text { prodi }\end{array}$ \\
\hline 6 & TELPMSPST & Varchar & 20 & $\begin{array}{l}\text { nomor telpon } \\
\text { prodi }\end{array}$ \\
\hline 7 & NMOPRMSPST & Varchar & 40 & nama ketua prodi \\
\hline 8 & EMAILMSPST & Varchar & 60 & email prodi \\
\hline
\end{tabular}

Tabel 4. Tabel tbjadwal

\begin{tabular}{|c|l|c|c|l|}
\hline No & \multicolumn{1}{|c|}{ Nama Field } & $\begin{array}{c}\text { Tipe } \\
\text { Data }\end{array}$ & $\begin{array}{c}\text { Lebar } \\
\text { Data }\end{array}$ & \multicolumn{1}{|c|}{ Ket. } \\
\hline 1 & Idjadwal* & Bigint & 20 & id jadwal \\
\hline 2 & Idkalender & Varchar & 15 & id kalender \\
\hline 3 & Kdpti & Varchar & 6 & $\begin{array}{l}\text { kode perguruan } \\
\text { tinggi }\end{array}$ \\
\hline 4 & Kdprodi & Varchar & 5 & kode prodi \\
\hline 5 & Kdmk & Varchar & 10 & kode mata kuliah \\
\hline 6 & Idruang & Varchar & 5 & id ruangan \\
\hline 7 & Namakelas & Varchar & 50 & nama kelas \\
\hline 8 & Hari & Varchar & 10 & hari jadwal \\
\hline 9 & Jammulai & Time & - & jam mulai \\
\hline 10 & Jamselesai & Time & - & jam selesai \\
\hline 11 & Kapasitas & Varchar & 3 & kapasitas kelas \\
\hline 12 & Semester & Varchar & 2 & Semester \\
\hline
\end{tabular}

Tabel 5. Tabel trnlm

\begin{tabular}{|c|l|c|c|l|}
\hline No & \multicolumn{1}{|c|}{ Nama Field } & $\begin{array}{c}\text { Tipe } \\
\text { Data }\end{array}$ & $\begin{array}{c}\text { Lebar } \\
\text { Data }\end{array}$ & \multicolumn{1}{|c|}{ Ket. } \\
\hline 1 & Idtrnlm* & Bigint & 20 & id transaksi nilai \\
\hline 2 & NIMHSTRNLM & Varchar & 15 & $\begin{array}{l}\text { nim transaksi } \\
\text { nilai }\end{array}$ \\
\hline 3 & KDKMKTRNLM & Varchar & 10 & $\begin{array}{l}\text { kode mata } \\
\text { kuliah transaksi }\end{array}$ \\
\hline 4 & NLAKHTRNLM & Varchar & 2 & $\begin{array}{l}\text { nilai akhir } \\
\text { transaksi }\end{array}$ \\
\hline 5 & KDPTITRNLM & Varchar & 6 & kode prodi \\
\hline
\end{tabular}

D. Perancangan Database

Class diagram adalah model statis yang menggambarkan struktur dan deskripsi class serta hubungannya antara class. Class diagram mirip dengan ER-Diagram pada perancangan database, bedanya pada ER-Diagram tidak terdapat operasi/metode. Berikut ini class diagram pada sistem yang

dibangun.

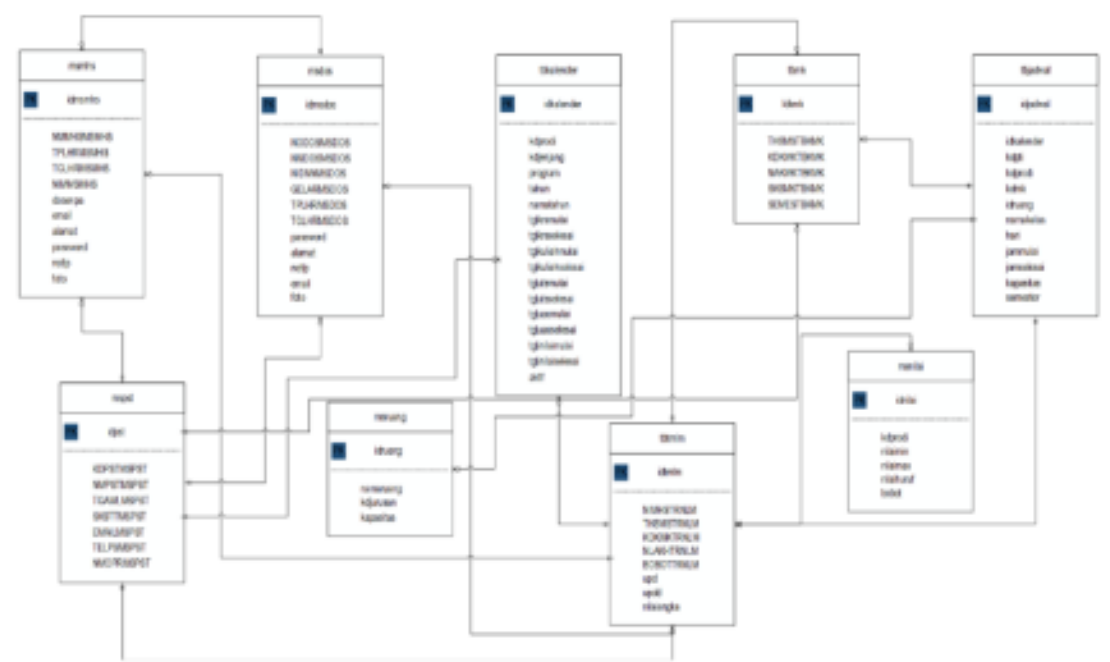

Gambar 4 Class Diagram Aplikasi Android Sistem Informasi Akademik Universitas Khairun Ternate 
E. Perancangan Database

Perancangan Database merupakan proses untuk menentukan isi dan pengaturan data yang dibutuhkan untuk mendukung berbagai rancangan sistem. Perancangan database menggunakan ERD (Entity Relationship Diagram).

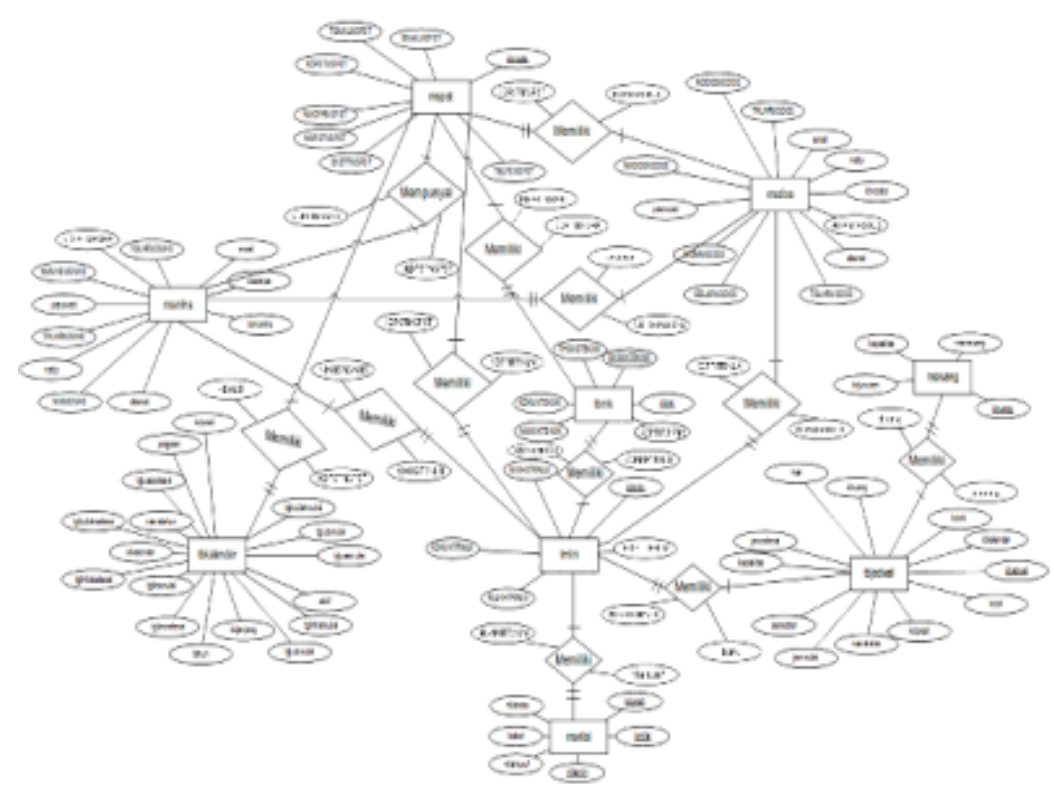

Gambar 5 ERD Aplikasi Android Sistem Informasi Akademik Universitas Khairun Ternate

\section{IV.HASIL DAN PEMBAHASAN}

A. Rekayasa Dan Pengembangan Sistem

1. Activity Diagram

Activity Diagram menggambarkan berbagai alir aktivasi dalam sistem yang sedang dirancang, bagaimana masing-masing alir berawal, descision yang mungkin terjadi, dan bagaimana mereka berakhir. Activity diagram juga dapat menggambarkan proses paralel yang mungkin terjadi pada beberapa eksekusi

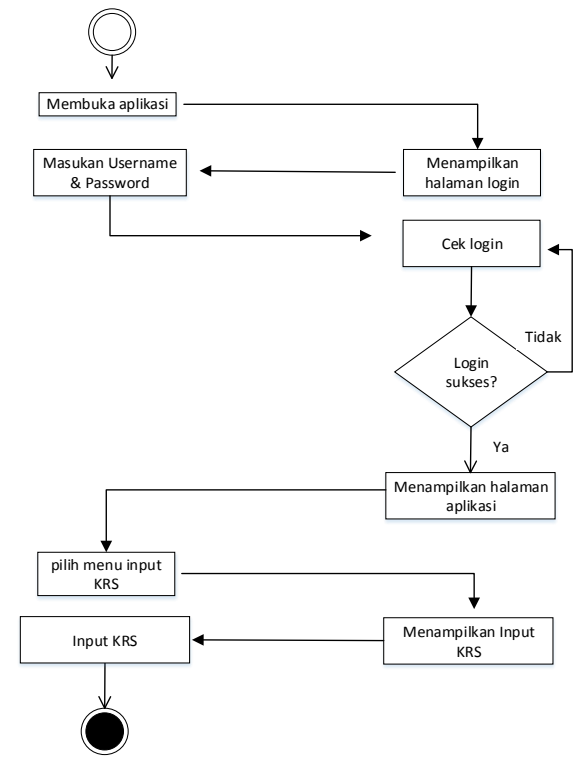

Gambar 6 Diagram Activity "Input KRS Mahasiswa”

Keterangan:

1. Membuka aplikasi terlebih dahulu,
2. Setelah tampilan halaman login muncul maka mahasiswa mengisi username dan password,

3. Apabila username dan password benar maka akan ditampilkan halaman utama aplikasi,

4. Apabila username dan password salah maka akan ditampilkan halaman login kembali,

5. Setelah tampilan halaman utama aplikasi muncul maka mahasiswa dapat memilihih menu input KRS,

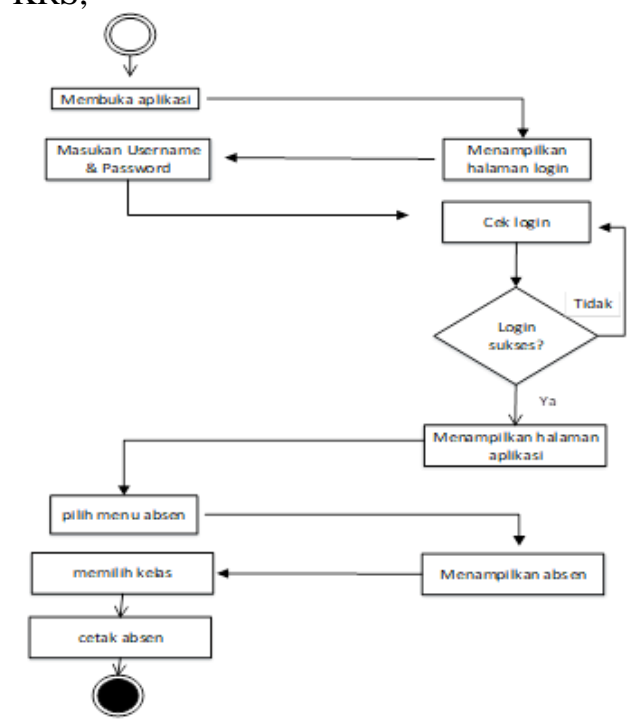

Gambar 7 Diagram Activity "Halaman absen dosen"

Keterangan:

1. Membuka aplikasi terlebih dahulu,

2. Setelah tampilan halaman login muncul maka dosen mengisi username dan password, 
3. Apabila username dan password benar maka akan ditampilkan halaman utama aplikasi,

4. Apabila username dan password salah maka akan ditampilkan halaman login kembali,

5. Setelah tampilan halaman utama aplikasi muncul maka dosen dapat memilihih menu jadwal,

6. Halaman absen dapat di akses, dengan memilih program studi yang di ampuh dan menekan tombol "Go". Kemudian cetak kelas yang dipilih.

\section{Sequence Diagram}

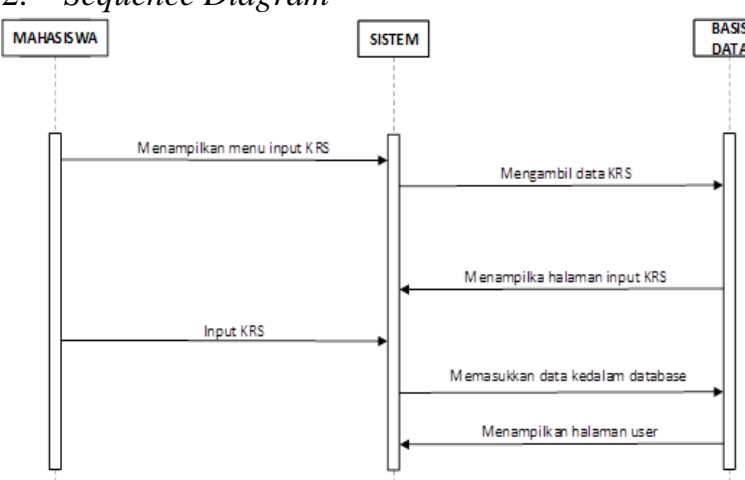

Gambar 8 Diagram Sequence "Input KRS Mahasiswa"

Keterangan:

1. Ketika mahasiswa telah login dan masuk ke halaman aplikasi, maka mahasiswa memilih menu input KRS.

2. Setelah memilih menu input KRS maka data tersebut akan di ambil dari basis data.

3. Kemudian akan tampil halaman input KRS dan mahasiswa bisa meng-input KRS.

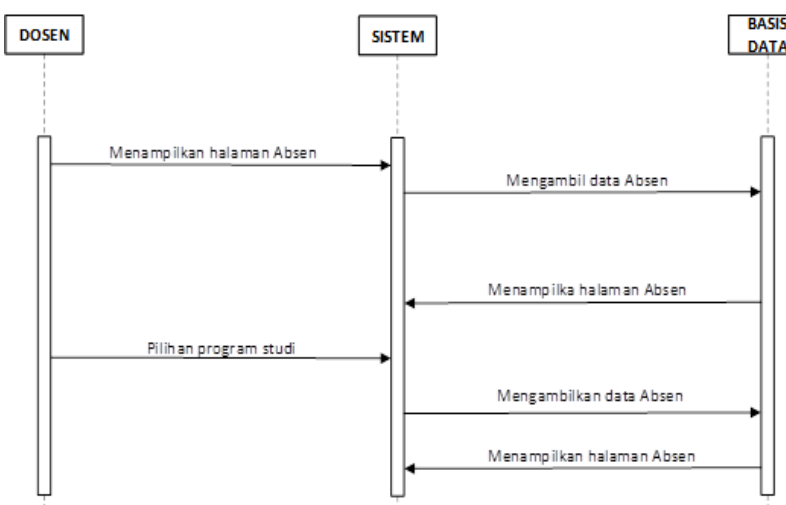

Gambar 9 Diagram Sequence "Halaman absen dosen"

Keterangan:

1. Ketika dosen telah login dan masuk ke halaman aplikasi, maka dosen memilih menu absen.
2. Setelah memilih menu absen maka data tersebut akan di ambil dari basis data.

3. Kemudian akan tampil halaman absen dan dosen bisa memilih program studi kemudian tampil halaman berdasarkan mata kuliah yang diajarkan dan absen dapat dicetak juga.

B. Impementasi Sistem

Dari perancangan sistem diatas maka dapat diimplementasikan hasil perancangan tampilan antarmuka "Aplikasi Android Sistem Informasi Akademik Universitas Khairun Kota Ternate" terdapat dua user di antaranya Mahasiswa yang dapat mengakses semua halaman yang ada pada halaman mahasiswa diantaranya dari keperluan input/cetak KRS, KHS, transkip nilai, jadwal perkuliahan, dan edit user. Dosen yang dapat mengakses semua halaman dosen diantaranya dosen dapat melihat jadwal mengajar, membuat absen kelas yang diajarkan, mengatur kembali KRS yang deprogram mahasiswanya, hingga menginput nilai dari mata kuliah yang diajarkan, dan mengedit data dirinya. Berikut ini tampilan di dalam sistem:

1. Halaman Input KRS

Halaman ini terdapat pada halaman user Mahasiswa, dimana halaman ini untuk proses perbelanjaan mata kuliah pada tahun akademik baru yang akan di tempuh mahasiswa tersebut dalam satu semester kedepan.

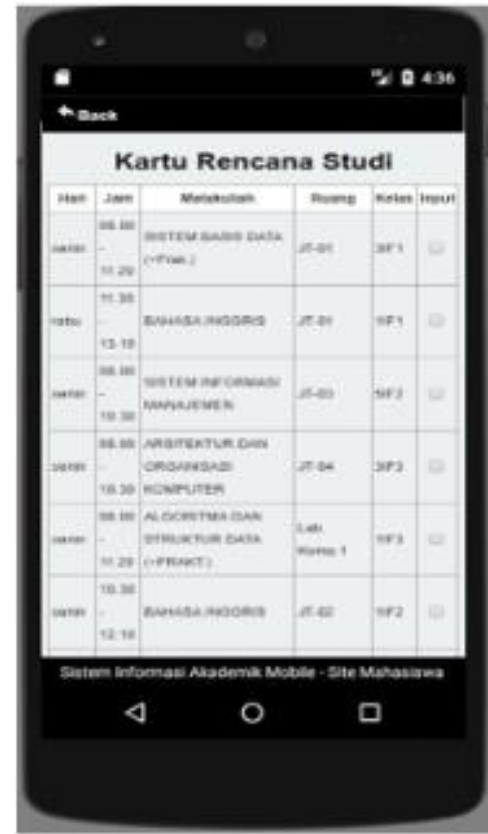

Gambar 10 Tampilan Halaman Login user mahasiswa dan dosen

2. Halaman KHS dan Transkip Nilai Mahasiswa Halaman KHS dan transkip nilai mahasiswa terdapat pada halaman utama user Mahasiswa, dimana halaman KHS bertujuan untuk pengecekan nilai oleh mahasiswa pada tahun akademik yang telah di lewati mahasiswa tersebut. Sedangkan halaman transkip untuk mengetahui seluruh nilai dan sks yang telah di 
tempuh mahasiswa selama perkuliahan pada sebuah program studi.

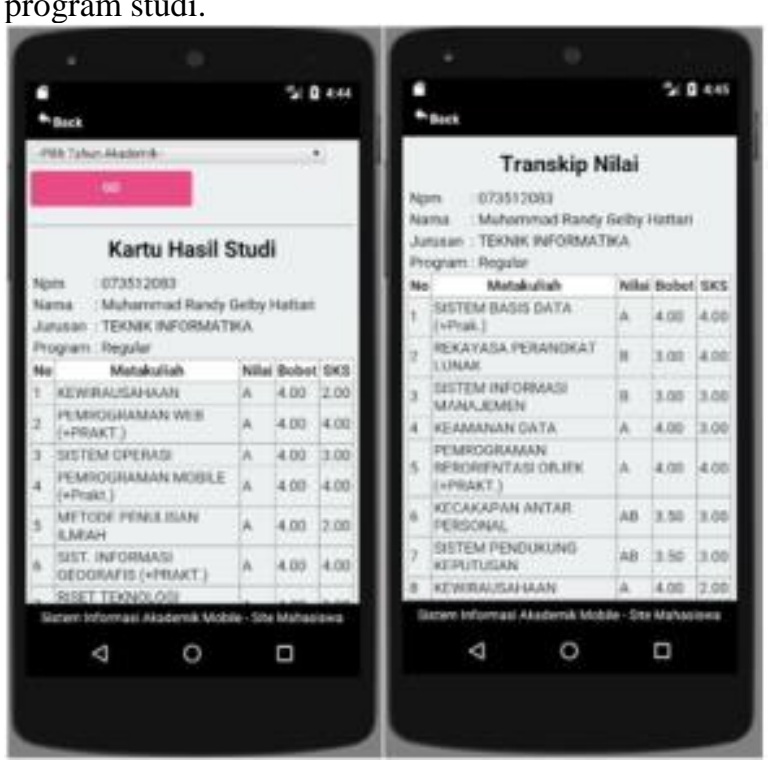

Gambar 11 Halaman KHS dan transkip nilai mahasiswa

\section{Halaman Jadwal dan Absen}

Halaman jadwal dan absen terdapat pada halaman utama user dosen, dimana halaman jadwal bertujuan untuk memberikan informasi kepada dosen tentang jadwal mengajarnya dalam tahun akademik yang sedang berjalan. Sedangkan halaman absen bertujuan agar dosen dapat mencetak absen kelas mata kuliah yang diajarkannya.

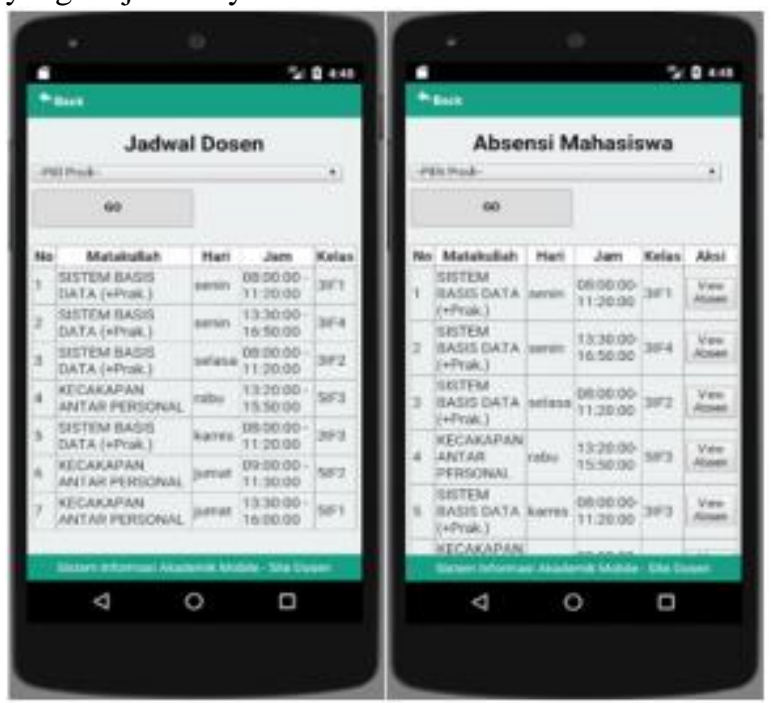

Gambar 12 Halaman jadwal dan absen dosen

\section{Pengujian Sistem}

Pada tahapan pengujian sistem ini, sistem akan diuji menggunakan pengujian blackbox, dimana pengujian blackbox tidak sampai ke algoritma sistem yang dibangun akan tetapi pengujian blackbox merupakan pengujian yang menguji fungsi-fungsi dari setiap menu pada sistem. Berikut ini hasil dari pengujian sistemnya.

\section{Halaman Login}

Tabel 6. Pengujian Halaman Login

\begin{tabular}{|c|c|c|}
\hline \multicolumn{3}{|c|}{ Pencuian halaman Login } \\
\hline \multicolumn{2}{|l|}{ Actor } & User Dosen dan Mahasiswa \\
\hline \multicolumn{2}{|l|}{ Menu } & Login \\
\hline \multicolumn{2}{|c|}{ Aktivitas Proses Rancangan } & $\begin{array}{ll}\text { 1. } & \text { Akses Halaman Login } \\
2 & \text { Masukan usemame dan password } \\
3 & \text { KIk tombol Login }\end{array}$ \\
\hline \multirow{2}{*}{ Tanda } & Peringatan Kesalahan & $\begin{array}{l}\text { Password atau usemame salah ! } \\
\text { OK }\end{array}$ \\
\hline & Kesesuaian Sistem & Dapat melakukan Login \\
\hline \multirow{2}{*}{ Hasil } & Worning & OK \\
\hline & Acoepf & OK \\
\hline \multicolumn{2}{|c|}{ Keterangan } & - \\
\hline
\end{tabular}
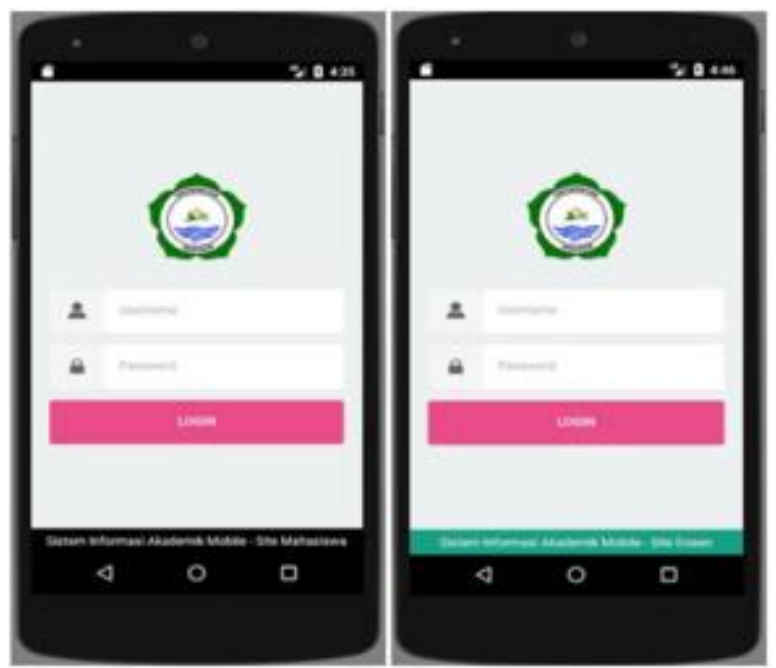

Gambar 13 Halaman Login

Gambar diatas menjelaskan tentang tampilan dari halaman login pada user mahasiswa dan user dosen.

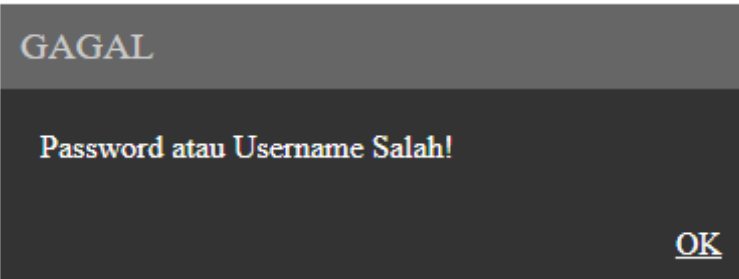

Gambar 14 Tampilan gagal Login

Pada gambar diatas menjelaskan tentang tampilan login ketika password atau username yang dimasukkan user salah.

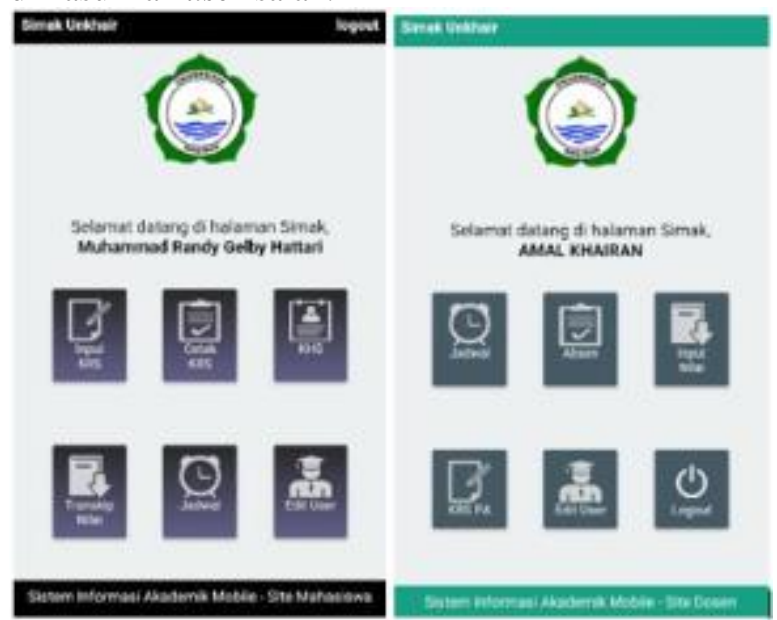

Gambar 15 Tampilan halaman utama 
Pada gambar diatas menjelaskan bahwa ketika login mahasiswa dan dosen berhasil maka akan tampil halaman utama seperti pada gambar diatas.

\section{Halaman Input KRS}

Tabel 7 Pengujian Halaman Input KRS

\begin{tabular}{|c|c|c|}
\hline \multicolumn{3}{|c|}{ Penguian halamen inout KRS } \\
\hline \multicolumn{2}{|c|}{ Actor } & User Mahasiswa \\
\hline \multicolumn{2}{|l|}{ Menu } & Input KRS \\
\hline \multicolumn{2}{|c|}{ Aktivtas Proses Rancangan } & $\begin{array}{l}\text { 1. Akses Halaman inpuf KRS } \\
\text { 2. Melakukan proses belanja } \\
\text { 3. Klik tombol simpan }\end{array}$ \\
\hline \multirow{2}{*}{ Tanda } & Peringatan Kesalahan &. \\
\hline & Kesesuaian Sistem & - \\
\hline \multirow{2}{*}{ Hasil } & Waming & - \\
\hline & Acceds & OK \\
\hline \multicolumn{2}{|c|}{ Keterangan } & - \\
\hline
\end{tabular}

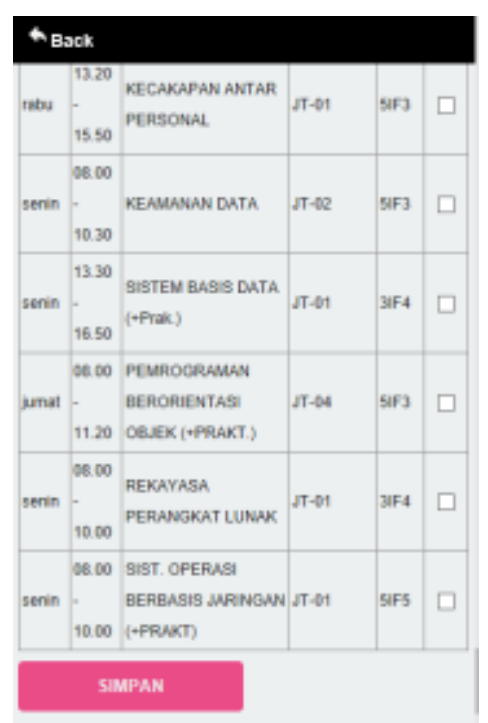

Gambar 16 Tampilan Halaman Input KRS

\section{Halaman Input Nilai Dosen}

Tabel 3 Pengujian Halaman Input Nilai

\begin{tabular}{|c|c|c|}
\hline \multicolumn{3}{|c|}{ Pengujian halaman Input Nila } \\
\hline \multicolumn{2}{|l|}{ Actor } & User Dosen \\
\hline \multicolumn{2}{|l|}{ Manu } & Inout Nlai \\
\hline \multicolumn{2}{|c|}{ Akthitas Proses Rancangan } & $\begin{array}{ll}\text { 1. } & \text { Akses Halaman input Nilai } \\
\text { 2. } & \text { Memilh Program studi dan Mata kuliah } \\
\text { 3. } & \text { Melakukan pengisian nilai mahasiswa } \\
\text { pada matakuliah yang tersebut. }\end{array}$ \\
\hline \multirow{2}{*}{ Tanda } & Peringatan Kesalahan & . \\
\hline & Kesesuaian Sistem & - \\
\hline \multirow{2}{*}{ Hasil } & Waming & . \\
\hline & Accept & OK \\
\hline \multicolumn{2}{|c|}{ Keterangan } & . \\
\hline
\end{tabular}

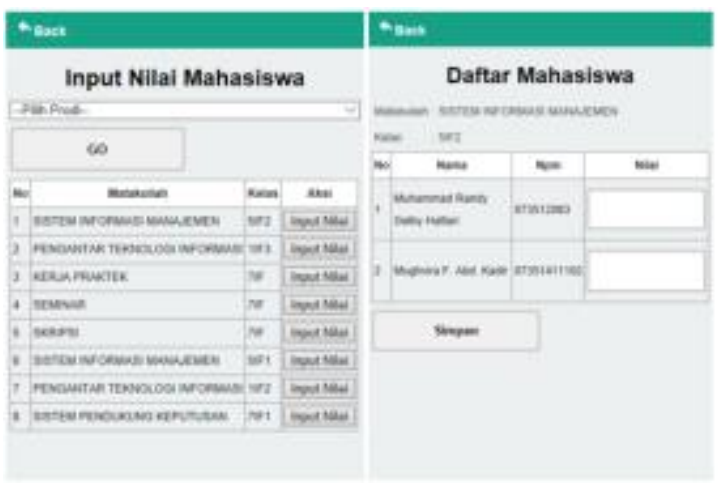

Gambar 16 Tampilan Halaman Input Nilai
D. Analisis

Tahap analisis merupakan tahapan yang dilakukan setelah melakukan pengumpulan data untuk mengidentifikasi dan mengevaluasi masalah, kesempatan - kesempatan, hambatan - hambatan yang terjadi dan kebutuhan-kebutuhan yang diharapkan sehingga dapat diusulkan perbaikannya.Ada beberapa tahap dalam melakukan analisis, yaitu analisis input, analisis output dan analisis cetak yang digunakan untuk mengetahui data apa saja yang diperlukan sistem. Serta analisis proses bertujuan untuk menganalisis proses apa saja yang bisa dilakukan oleh user terhadap sistem. Pembuatan proses ini dengan menggunakan use case diagram, activity diagram, sequence diagram dan entity relationship diagram (ERD).

Usecase yang dibuat yaitu usecase melihat login user dosen maupun mahasiswa, usecase melihat KHS dan KRS mahasiswa, dan usecase input nilai dan KRS PA user dosen. Sedangkan activity diagram yang dibuat untuk mendiskripsikan kegiatan atau aktivitas semua user yang terdapat didalam sistem seperti meng-update melihat serta mencetak data untuk Sequence diagram digunakan untuk interaksi objek pada usecase dan sistem yang dibuat, dan untuk ERD digunakan untuk membuat pemodelan data utama dan akan membantu mengorganisasi data dalam suatu proyek kedalam entitas-entitas dan menentukan hubungan antar entitas sehingga terbentuk sebuah relasi yang baik untuk hubungan masing-masing entitas.

Pada tahapan implementasi sistem yang telah dibangun seluruh user yang terdapat pada sistem hanya ada dua yaitu user mahasiswa, harus melakukan login untuk dapat masuk dalam sistem jika setelah password dan username yang dimasukan tidak sesuai dengan data yang ada pada database maka sistem akan memberikan informasi bahwa password dan username yang anda masukan salah setelah itu sistem juga akan memberikan link untuk menampilkan halaman login kembali. Setelah mahasiswa berhasil login masuk kedalam sistem maka akan diberikan hak akses sesuai dengan kebutuhan yaitu dapat mengakses menu input KRS, KHS, Transkip nilai, Jadwal perkuliahan dan edit user. Sedangkan untuk user dosen juga harus melakukan login untuk dapat masuk dalam sistem jika setelah password dan username yang dimasukan tidak sesuai dengan data yang ada pada database maka sistem akan memberikan informasi bahwa password dan username yang anda masukan salah setelah itu sistem juga akan memberikan link untuk menampilkan halaman login kembali. Setelah dosen berhasil login masuk kedalam sistem maka akan diberikan hak akses sesuai dengan kebutuhan yaitu dapat mengakses menu input nilai, KRS PA, Absen, Jadwal dosen dan edit user. 


\section{PENUTUP}

\section{A. Kesimpulan}

Berdasarkan penelitian yang dilakukan dan telah dibahas pada bab-bab sebelumnya, maka dapat diambil sebuah kesimpulan sebagai berikut:

1. Perancangan sistem dimulai dengan membuat gambar-gambar dari diagram-diagram yang digunakan seperti use case diagram untuk mendiskripsikan sebuah interaksi antara satu atau lebih user dengan sistem yang dibuat, activity diagram yang menggambarkan aktivitas yang terjadi dalam sistem, sequence diagram yang menjelaskan interaksi objek pada use case, class diagram menggambarkan struktur sistem dari segi pendefinisian kelas-kelas untuk membangun sistem, dan diagram entity relationship diagram (ERD) pemodelan data utama dan akan membantu mengorganisasi data dalam suatu proyek kedalam entitas-entitas dan menentukan hubungan antar entitas.

2. Pembuatan sistem menggunakan metode prototype yang dimulai dari pengumpulan datadata berdasarkan kebutuhan user terhadap perangkat lunak yang dibuat agar sistem yang dibagun dapat sesuai dengan keinginan user

3. Implementasi sistem dimulai dari pemilihan level oleh user kemudian melakukan login, sebelum masuk ke dalam halaman utama harus memasukan password dan username untuk dicocokan dengan data yang terdapat dalam database, jika password dan username yang dimasukan sesuai dengan data yang ada pada database maka sistem akan menampilkan menumenu sesuai dengan user yang masuk, sedangkan jika password dan username tidak sesuai dengan data yang ada pada database maka sistem akan menampilkan pemberitahuan bahwa username dan password salah dan silahkan login kembali dan hal ini akan berlaku untuk semua user baik dosen maupun mahasiswa yang terdapat dalam sistem.

4. Dengan semua tahapan yang dilalui maka sistem ini dikatakan berhasil dan sesuai dengan apa yang diharapkan. Sistem ini dapat digunakan untuk kebutuhan akademik di Universitas Khairun.

B. Saran

Hasil dari Perancangan Aplikasi Android Sistem Informasi Akademik Universitas Khairun Ternate ini masih terdapat kekurangan yang masih belum bisa dipenuhi yaitu belum adanya akses untuk user lain layaknya pada aplikasi website Sistem Informasi Akademik Universitas Khairun ini, diharapkan kedepan nanti dapat dikembangkan aplikasi tersebut sehingga aplikasi dapat dimanfaakan oleh pihak-pihak yang membutuhkan aplikasi tersebut.

\section{DAFTAR PUSTAKA}

[1] Fikri, Imaduddin Al, Darlis Herumurti, and Ridho Rahman H. 2016. "Aplikasi Navigasi Berbasis Perangkat Bergerak Dengan Menggunakan Platform Wikitude Untuk Studi Kasus Lingkungan ITS. Jurnal Teknik ITS. Vol. 5. No.1.

[2] Moh. Ihsan Alhudri. 2014. Sistem Informasi Pelayanan Jamaah Umroh Berbasis Web Pada Pusdai Tour \& Travel. Skripsi Program Studi Sistem Informasi Fakultas Teknik Dan Ilmu Komputer Universitas Komputer Indonesia. Bandung.

[3] Safaat H., Nasruddin. 2012. Pemrograman aplikasi mobile smartphone dan tablet PC berbasis android. Penerbit Informatika.

[4] Solichin, Ahmad. 2005. Pemrograman Web dengan PHP dan MySQL. Universitas Budi Luhur. Jakarta.

[5] Warno. 2012. Pembelajaran Pemrograman Bahasa Java Dan Arti Keyword. Jurnal Komputer. Vol. 8. No. 1. 